\title{
Concentration, consolidation, and control: How big business dominates the food system
}

\author{
Book review by Steven Dukeshire, Dalhousie University
}

\section{Foodopoly: The Battle Over the Future of Food and Farming in America}

Hauter, W. (2013). Foodopoly: The battle over the future of food and farming in America. New York: The New Press.

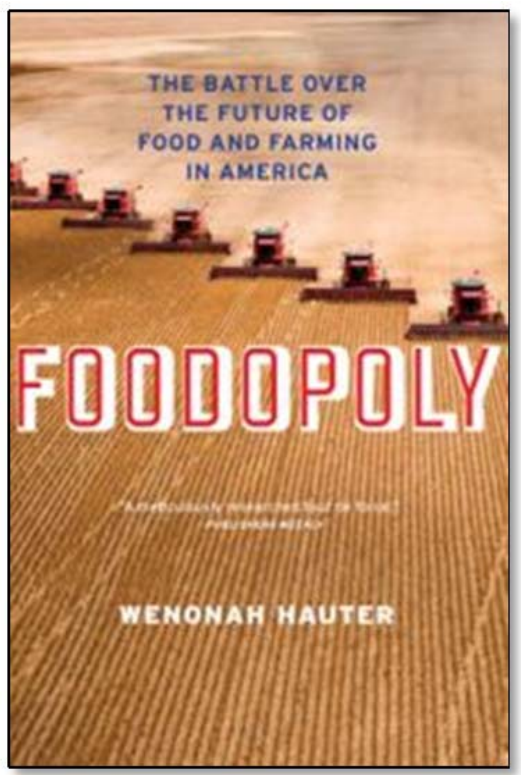

Published online December 20, 2013

Citation: Dukeshire, S. (2013). Concentration, consolidation, and control: How big business dominates the food system [Book review of Foodopoly]. Journal of Agriculture, Food Systems, and Community Development, 4(1), 171-173. http://dx.doi.org/10.5304/jafscd.2013.041.010

Copyright (C) 2013 by New Leaf Associates, Inc.

Foodopoly, a meticulously researched book by focused on a single country that traces the historical and political changes that have transformed the food system. The book highlights how business and political elites have altered regulatory and business institutions to create the conditions whereby large food conglomerates can operate unfettered, and with the aid of a government seemingly interested in serving business over public interests. Inevitably, as has happened in so many other countries, and as detailed in Foodopoly, the result of this shift to a globalized food system has had many detrimental impacts. These now all-too-familiar

Dr. Steven Dukeshire is an assistant professor in the Faculty of Agriculture, Dalhousie University, where he teaches psychology and sociology. His main research interest focuses on how, in the context of a complex and opaque food system, consumers make informed dietary choices and are able to trust that what they eat is healthy and safe. He can be reached at steven.dukeshire@dal.ca. negative consequences of globalization include farmers being driven off their land, exploitation of workers in factories with dismal working conditions, environmental degradation due to weakening laws and limited enforcement, and questionable food safety and animal welfare practices. However, what grabs one's attention in Foodopoly is that this case study is not based on a small, developing nation, but rather on the United States of America, the bastion of capitalism and champion of globalization. Foodopoly effectively points out that the United States is not immune to the negative impacts of globalization and sounds the alarm that the health and sustainability of the country's food system are under threat.

It is clear from the beginning of the book what Hauter's position is on the current food system. She believes that consolidation and concentration has undermined food policy, fostered an unsafe and unsustainable production and distribution system, and led to the demise of the family farm. 
The body of the book is a riveting account of how business and political forces combined to use their power to reshape the food system to favor a few corporate elites at the expense of both the social and physical environments. The final chapters suggest a way forward, but lack the intensity of the main narrative. For although Hauter correctly asserts that change needs to happen at the policy level, the reader is left wondering what role she or he can play to effect the required policy reforms.

The first three chapters of Foodopoly describe how a disorganized and fractured food production and distribution system became organized and (seemingly) far more efficient. These chapters provide a fascinating study of how the largest food retailers, led by Walmart, have created conditions to force increased food efficiency throughout the entire food chain. If one stopped reading after just the first three chapters, one would come away with the impression that but for a few minor problems, we now have a much improved food system with far-reaching benefits to the consumer.

Any impressions that consolidation of the food system has been largely beneficial to individual consumers and society as a whole are quickly dispelled in subsequent chapters. In general, the best chapters of Foodopoly are those that compare practices in the current food system to practices that had existed previously. These contrasts bring to the foreground the problems of an agri-food model based on concentration and consolidation. In chapter 5, Hauter presents the contradictions and consequences that emerge from the principles and philosophies of a highly capitalistic mode of food production subsuming the higher ideals characteristic of organic farming. In short, the introduction of national organic standards in 1997 meant that large companies could essentially take over the organic industry by meeting these minimum production standards while ignoring all the other ideals and values of the organic movement. The absurdity of the paradox of huge corporations meeting the principles and ideals of organic food production is perhaps best captured by Hauter's description of the goals and activities of the Organic Trade Association (OTA). The OTA is controlled not by small organic farmers, but by multimillion-dollar food companies actively lobbying to (further) reduce organic standards. Fifteen years after the introduction of national organic standards, the U.S. is now left with an organic food industry that is being led and formed mainly by capitalist principles rather than the promotion of socially, economically, and ecologically just food production.

Hauter also meticulously documents how industry has effectively altered rules, regulations, and enforcement to create an environment friendly to food businesses. In a thoroughly compelling manner, Hauter brings to the fore the immense political power of the food industry and how that political power is wielded within the neoliberal ideology of the U.S. government to minimize any regulations that may inhibit business or the acquisition of profit. For example, chapter 6 describes in detail the implementation of the Hazard Analysis and Critical Control Points system (HACCP), a system and philosophy that essentially allowed the meat processing industry to become self-regulatory and do away with government inspectors regulating the production line. As a result, food that previously would have been removed by inspectors is now allowed to continue through the processing line. This change has resulted in the processing rather than removal of meat with feces contamination, oozing wounds, tumors, and other undesirable features. Such processing is justified through the use of the HACCP system that supposedly addresses these safety and quality issues through various technological means to remove sources of contamination, including the routine use of ammonia, chlorine, trisodium phosphate, and irradiation as the meat progresses through the processing line. The result of HACCP, according to Hauter, has been the removal of virtually all oversight by government inspectors, less humane treatment of animals, increasingly dangerous working conditions, the loss of smaller meat processors, and a lowered quality and safety of food.

Hauter does much more than just point out the problems and issues presented by a globalized food system in the United States. In essence, Foodopoly lays out the case that American democracy is being subverted by powerful corporate interests that control important government decisions. What makes Foodopoly so powerful is that 
Hauter clearly and concisely demonstrates the mechanisms by which this corporate influence is wielded. Further, by revealing the contradictions of a food system that promotes itself as vastly superior in every respect, Hauter raises the specter that the current globalized food system is actually inefficient and in many ways harmful to people, animals, environment, and society as a whole. She not only lifts a veil of secrecy regarding business practices of actors in the food industry, but also places food system consolidation and its impacts in historical and political context. As a result, Foodopoly is not just a captivating read, but also a potential tool in the arsenal of those who wish to create a more sustainable and humane food system. 